doi: 10.21564/2225-6555.2018.13.130823

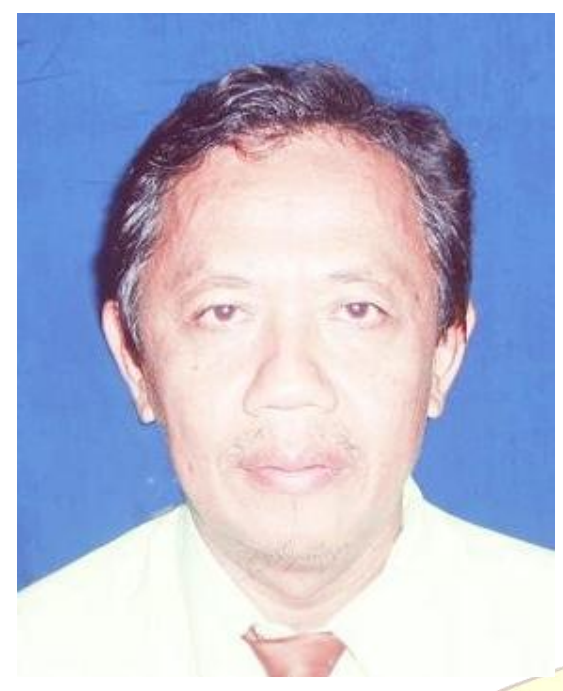

\title{
THE LEGISLATIVE'S INQUIRY RIGHTS AHEAD OF CORRUPTION ERADICATION COMMISSION PERFORMANCE
}

\author{
Azis Setyagama, \\ PhD in Law, \\ Associate Professor, Lecturer of Constitutional Law \\ at Law Faculty, \\ Panca Marga University, \\ Probolinggo, East Java, Indonesia \\ e-mail: Setyagama.azis@gmail.com
}

This study proposed to disclose the legislative's Inquiry Rights ahead of corruption eradication commission (KPK) performance since many officials state are involved in corruption which includes the members of the Legislative Assembly (DPR). The inquiry rights appeal regarding the performance and budget management of KPK apparatus. It is appeal due to electronic identity card (E-KTP) case which involved members of legislative assembly. This study uses nominative approach pointing to the law No. 17/2014 concern with the MPR, DPR, DPRD and DPD and law No. 30/2002 concern with commission eradication corruption. In addition, it also uses the sociological approach in term of public response to The Legislative Assembly's inquiry rights appeal. This study revealed that the Inquiry right appealed by Legislative Assembly constitutionally was legal since it was one of the three right of legislative assembly. However, the inquiry right appealed by Legislative assembly regard with Id-card case potentially to hinder the $K P K$ 's performance to prevent any corruption act in Indonesia. Additionally, this appeal also creates pros and cons because the society does not in line with it.

Keywords: Inquiry rights; Legislative Assembly; KPK; Corruption act; E-KTP.

Азіс Сетьягама, доктор філософіi, дочент, викладач юридичного факультету, Університет Панча Марга, Східна Ява, Індонезія, м. Проболінго

e-mail: Setyagama.azis@gmail.com

Конституційне право на проведення розслідувань Комісією по боротьбі 3 корупцісю в Індонезії.

У статті зроблено спробу проаналізувати права Комісії по боротьбі з корупцією (КБК) з розслідування діяльності членів Законодавчих зборів Індонезії. Це викликано тим, щуо багато офічійних осіб заявляють про корупчійні діяння, в яких підозрюються $і$ члени Законодавчих зборів, $i$ звертаються в апарат КБК із запитом про можливість участі останніх в управлінні бюджетом країни. Запит стосується також апеляції у зв'язку $з$ використанням членами Законодавчих зборів при голосуванні електронного посвідчення особи. При аналізі використовувалися положення Закону № 17/2014 про Народний консультативний конгрес, Законодавчі збори, Раду регіональних представників $і$ Раду народних представників, а також Закону № 30/2002 про Комісію по боротьбі з корупцією. Для вивчення громадської думки про право на апеляцію в Законодавчі збори використано результати сочіологічного опитування. Дослідження показало, що право на розслідування, надане Законодавчими зборами, відповідно до Конституиії $\epsilon$ законним, оскільки воно 
виступає одним із трьох прав Законодавчих зборів. Проте право проведення опитування про законність використання електронного посвідчення особи, розглянуте Законодавчими зборами, фактично перешкоджає виконанню КБК своӥх обов'язків щцодо запобігання будьякого корупиійного діяння в Індонезії. Крім того, проведене опитування також має свої плюси і мінуси, оскільки суспільство ще не готове изього.

Ключові слова: право на розслідування; законодавче зібрання; комісія по боротьбі 3 корупцією; корупційний акт; електронне посвідчення особи.

\section{Introduction.}

In the 1945 Constitution of Indonesia, it is mentioned that "To build a state government of Indonesia shall protect all Indonesian and their entire native land, and in order to improve the public welfare, to advance the intellectual life of the people and to contribute to the establishment of a world order based on freedom, abiding peace and social justice, the national independence of Indonesia shall be formulated into a constitution of the sovereign Republic of Indonesia which is based on the belief in the One and Only God, just and humanity, the unity of Indonesia, democracy guided by the inner wisdom of deliberations amongst representatives and the realization of social justice for all Indonesian". Hence, it is necessary that the state apparatus is clean from colonialism, corruption, and nepotism (KKN), as a requirement to achieve the Indonesian nation welfare. Thus, it needs an institution that handles the problem of corruption. Responding that, Indonesia formed the institution named Corruption Eradication Commission (KPK). The Indonesia Law No. 302002 that the Corruption Eradication Commission is a juridical foundation of KPK institutions. The existence of this institution is to handle the problem of corruption optimally considering that other law enforcement agencies can not solve corruption in Indonesia.

The inquiry rights appealed by the Legislative Assembly (DPR) emerged because many DPR members are listed within some corruption acts. Therefore, the House seeks to take retaliatory action by appealing the DPR's inquiry rights toward KPK concerning law violation and authority abuse provided by Constitution. The use of this inquiry rights arises since the KPK rejected the request of the Legislative Assembly to record Miryam. S. Haryani case concerning money distribution to members of the DPR in the process of Electronic ID card budget (Radjab, 2018). 
The DPR's inquiry right is basically an institutional right from the Law to investigate the misuse of law and government policy related to the important, strategic and broad-based impact on the life of the nation. However, the inquiry rights initiated by the house has raisen pros and cons since KPK is still independent institutions that have the public's trust to eradicate corruption so far. The KPK position as an independent institution can not be supervised by the Parliament because it will hamper the process of law enforcement to eradicate corruption criminal acts.

On the other hand, some of those presume that KPK is a Super Body institution who has high authority which may be misused by its apparatus in capturing perpetrators of corruption. Thus, KPK needs supervision for its performance and the use of operational fund. This supervision includes the DPR oversight so that it has the right to file its inquiry right. The main issue is whether the position of the Commission entered as an executive or an independent institution can not be supervised by the Parliament.

Indeed, before the decision of the Constitutional Court, there has been no clarification on the position of KPK. KPK is included in the executive domain so that the DPR has the authority to conduct the supervision including the inquiry right against KPK. The authority of the Legislative Assembly to propose an inquiry rights does not exactly loosen KPK's authority to eradicate corruption in Indonesia. It instead strengthens KPK to eradicate corruption because the duty of the Legislative Assembly is also supervising.

\section{Research Methodology.}

The study uses a normative approach based on the juridical analysis based on Law No. 17/2014 concern with MPR (People's Consultative Assembly), DPR (Legislative Assembly), DPRD (Regional Legislative Assembly) and DPD (Regional Representatives Council) as well as Law no. 302002 concern with the Eradication of Corruption, which is previously defined normatively regarding the purpose of the establishment of the Corruption Eradication Commission (KPK), its duties and authorities dealing with the problem of corruption in Indonesia. This study also 
applies sociological analysis where the existence of Eradication Commission institution is urgently formed considering Indonesia include as a corrupt country in the world.

\section{Research Results and Discussion.}

\subsection{Legislative Assembly within the Presidential System.}

The Legislative Assembly, in a presidential government system, functions as an institution that oversees the running of the government. The House only serves to supervise the president without being able to topple the president. In order for such supervision to work properly, the Parliament should have the right and functions guaranteed in the Constitution. Dirga, Wirawan and Purnomo (1985) set forth Some functions of the DPR:

1. Determining the policy and constructing laws. Legislative Assembly is granted an initiative right - the right to propose laws to the government rather than only the budgeting right to set state budget.

2. Controlling and supervising the Executive Assembly in term of maintaining the government's actions based on the policies established in the provisions of the legislation. To carry out this task, the Legislative Assembly has special rights guaranteed by law.

In a state administration system that embraces a presidential system, the legislature has the following functions:

a. Legislative Function

In a modern state, the majority of legislative drafting is prepared and formulated by the executive assembly, while the parliamentarians discuss and make changes as necessary. In the process of legislation, the role of the municipal assembly committee is very small and the material concerned on the public interest. This is not surprising for in modern countries that the executive assembly is expected to play an active role in the state leadership for the welfare of society. The law produced by the legislature is not widely used because the legislative council has expertise lacks on what material should be regulated in law. Therefore, the law is dominated by the government or executive assembly because they have wider knowledge about their 
respective field.

Concern with the balance of knowledge and skills of the legislature on the capabilities and expertise of the government, many countries use the experts to manage and help thier Duties. It is need by the Legislative Assembly due to thier right to make changes to the draft law on the state budget revenues fundamentally in the discussion of the budget law draft and the acceleration of state expenditure. Thus, the assistance of experts for members of the people's legislative assembly is needed (Dirga, Wirawan and Purnomo (1985).

b. Controlling functions

Since the authority possessed by the House of Representatives is limited, it is generally accepted that its function of oversight is the most important function of the people's legislature. The Legislative Assembly is obligated to oversee the course of government exercised by the government or the executive assembly based on the policies laid in the law. This supervision may be exercised by the rights already embedded in the legislature such as special supervisory rights, such as; the right to ask, interpellation rights, the right of inquiry, etc.

c. Function of Budget

The Legislative Assembly as the representative of the people can determine the income and expenditure of the state which is essentially the society's money. The use of public money for state expenditure are derived from foreign aid or loans and tax collection to the people as a source of state income. Regarding to taxes imposed on taxpayers as a contribution to the state, the Legislative Assembly is authorized by taxpayers for a wide range of tax policy issues as one source of state financing. Government expenditures for state expenditure should be accountable to the source of the people as taxpayers and the ultimate responsibility in case of mistakes and errors.

In fact, the people's legislature has the authority to revise and change the budget set by the government of the executive members. In many cases, the people's legislatures give approval to executive designs that are entirely part of the budget function of the people's legislature.

d. Function of Official Selection 
In our constitutional system, after the New Order regime collapsed and passed on the reform Order, the election of certain state officials must get the approval of the people's legislature, indicating that the appointment of certain strategic state officials must obtain the consent of the people through their representatives of the people's councils. For example; the post of Supreme Court Justice, Chief Justice of the Supreme Court, Chief of Police, Commander of ABRI, etc.

e. Function of International Relations

The function of the People's Legislative Council in the field of international relations is to give approval to international agreements made by the government or the executive assembly. Parliamentary approval is required so that the contents of the treaty can be binding on all represented citizens. After the parliament has ratified international agreements by passing new legislation, the government is authorized to implement the international agreement (Napitupulu, 2007).

\subsection{The Regulation for the use of DPR's inquiry right.}

Supervision by the Legislative Assembly on the right attached to this institution is to carry out the running of government executed by the government or the executive body. The right of the Legislative Assembly in order to exercise oversight of the government's proceedings, among the following:

\section{Right to Ask.}

This right of inquiry is related to the right of the Legislative Assembly in terms of supervision to the government, by asking a question or inquiring government policy. In a country that embraces the parliamentary system, the role of the Legislative Assembly is enormous for all governmental or executive policies which are usually asked by the Legislative Assembly to avoid public attention to an event. The right to question the Legislative Assembly will be answered by the government through competent departments. In Indonesia, the right to ask to the Legislative Assembly has very little political effect because we do not embrace the parliamentary system in the implementation of the state, so the right of inquiring from the Legislative Assembly is not altogether against the government policy. This is because Indonesia embraces the presidential system. 
2. Interpellation Rights.

Interpellation rights are the right of the Legislative Assembly to request information from the executive or government in the event that the government takes the policy of a particular field. The government is obliged to provide an explanation to the Legislative Assembly in a plenary session which Legislative Assembly on the positive and negative side of the government's explanation and ends by voting whether government policy is acceptable or rejected.

The right of Interpellation in the parliamentary system is a stepping stone to advance in a no-confidence motion that will end with the fall of the government and followed by the dissolution of parliament for re-election. On this no-confidence motion, the atmosphere of jabs and anxieties happen between the legislative and the executive assembly although the Legislative Assembly has the right of interpellation not to overthrow the government.

3. Inquiry rights (Enguate).

The inquiry right is the right of the legislative assembly members to conduct an independent inquiry into any field. To conduct an investigation into a particular area of government policy, the Legislative assembly established a committee in charge of investigating the policies of the government whose results were reported to members of the Legislative Assembly. After the members of the Legislative Assembly receive a report from the inquiry committee, the formulation of Legislative Assembly members' opinion regarding the government's policy should be considered by the Government. In Indonesia, the Legislative Assembly inquiry is regulated in the law, and the House inquiry right here is just a warning to the government to be careful to take wisdom without overthrowing the government because the system used in Indonesia is presidential government system in which the government or president can not be imposed by The Legislative Assembly.

The Inquiry right is the right of the Legislative Assembly (DPR) to investigate important and strategic government policies and to have a broad impact on the life of the people and the state that is suspected to be contrary to the prevailing laws and regulations. This provision is regulated by Law no. version 27, Paragraph 3 of 2009 
concerning the Consultative Assembly, the Legislative Assembly, and the Regional Legislative Assembly, should explain the right to inquiry: "The right of the Legislative Assembly to investigate the implementation of a law and government policy regarding to the important, strategic, and broad impact on the society life, nation and state allegedly contrary to the laws and regulations ".

The polemic regarding the use of the Legislative inquiry right is addressed to an independent institution, the Corruption Eradication Commission (KPK), which is commissioned by law to eradicate corruption in Indonesia. So, it can be said that the Legislative Assembly intervenes the KPK's authority to eradicate corruption. This raises the opinion of pros and cons against the DPR inquiry right toward KPK.

Pros opinions on the right of inquiry have the following reasons:

1. KPK, as a super body institution whose broad authority is prone to be abused by its apparatus, so it is necessary to monitor the performance of KPK and the budget used. Due to its position as an independent institution, they arbitrarily set a person as a perpetrator of corruption by the presence of surveillance Right from the Legislative Assembly.

2. The Legislative Assembly can control over the implementation of the law, as a function of the legislator. The Parliament can assess whether the implementation of the law is appropriate or not even violate the provisions of the law itself.

3. The KPK is in the executive domain, so the DPR has the right to oversight through the DPR's right to inquiry. In the Indonesian state administration system, the KPK is included in the executive sphere as the government's supporter in the eradication of corruption. Thus, the DPR has the right to control over the KPK whose duties are independently performed.

4. The KPK and its operational institutions use the State Budget (APBN), so the DPR has the right to supervise the performance and use of funds from the State Budget. The DPR's position is very strong to control the state budget because it has authority to approve the budget proposed by the government. In Article 23 of the 1945 Constitution of the Republic of Indonesia (NRI) of 1945 that the State Budget of Expenditure (APBN) is stipulated annually by law. 
5. The existence of DPR inquiry right will better the KPK performance to eradicate corruption crime. KPK will be more careful in recruiting perpetrators of corruption by the supervision of the Legislative Assembly through its inquiry right.

Likewise, the cons opinion has different reasons as following points, are:

1. DPR will weaken KPK to eradicate corruption crime in Indonesia. The great authority in the law and the independence of this KPK will be torn apart by the inquiry right of the Legislative Assembly.

2. The DPR inquiry right is issued full of personal conflict interests because many members of Legislative Assembly are involved in corruption crimes, especially in E-ID card case which dragged the DPR chairman to suspect corruption, Miryam S Haryani. Thus, the DPR's inquiry right is not based on the general truth and the interests of the community but the interests of the members of the DPR itself.

3. The process of forming DPR's inquiry right toward KPK violates the law so that it is illegitimate based on Law no. 17 of 2014 on the MPR, DPR, DPD and DPRD, which stated in Article 20 Paragraph (2) contains provisions that the membership of the Parliament Inquiry Committee consists of all elements of the fraction in the House. The fact of the special committee formed for the DPR's right is that not all factions approved it.

4. The Legislative Assembly right of inquiry (Pansus DPR) takes an illogical action by asking the corruption prisoners for fundamental information based. By asking people who have dealt with the KPK to show that the House only saw from the side of ugliness. Likewise, the committee of the Special Committee of the Legislative Assembly only collects expert information from the pro-parties which weaken KPK, in other words. They consider that KPK has gone too far beyond its authority.

\subsection{Weakening Corruption Eradication in Indonesia by Rights of} Parliament Inquiry Existence.

As mentioned previously, the existence of Legislative Assembly inquiry right will weaken the KPK in eradicating corruption criminal acts in Indonesia. It will obstruct KPK to eradicate corruption in Indonesia. Actually, KPK has a noble task to 
eradicate corruption in Indonesia because other institutions cannot work properly to combat corruption.

The problem of corruption in Indonesia has become a culture and plague that infected all lines of nation and state life. One of the efforts to overcome the disease of this nation is to establish a new state institution. The establishment of this institution aims to assist the implementation of tasks done by the state institutions which is less effective to eradicate corruption in Indonesia.

Actually, institutions that deal with corruption and other criminal cases have been long existed such as Police and General Attorney. Yet, the existence of these two institutions is less effective. The members are even involved in a corruption case. As an effort to achieve the clean state apparatus and the corruption eradication, the government needs to establish a new state institution that is the Corruption Eradication Commission (KPK) with the juridical foundation of Law no. 30/2002 regarding the Corruption Eradication Commission.

KPK has a noble purpose of combating corruption which is increasingly harmful to the mind of state apparatus, especially state officials who should provide an example to its citizens. Historically, KPK was born from an assumption that law enforcement by the Police and Prosecutor's Office is not working properly. The high number of corruption committed by state officials makes people lose confidence in the existing institutions which then stimulate the government to establish new state institution focusing on corruption eradication. KPK is a state institution established with the aim of improving the efficiency and effectiveness of efforts to eradicate corruption. It is independent and free from any influence of power to carry out its duties and authorities. In performing its duties, KPK is guided by five principles, such as: principles of legal certainty, openness, accountability, public interest, and proportionality. It is responsible to the public and submits its report periodically to the President, DPR and BPK.

\section{Conclusion.}

The submission of the DPR's inquiry rights toward the KPK is the constitutional right of the Legislative Assembly in terms of supervising the execution 
of the state conducted by the executive, in which the position of KPK is included in the executive domain so that it is included in the DPR's supervision, logically. However, KPK has an independent position to carry out its duty to eradicate the corruption in Indonesia. The existence of this inquiry right appeal regarding the performance of KPK is an intervention to law enforcement in the field of corruption. Thus, this appeal is considered as weakening the position of KPK to eradicate corruption in Indonesia.

\section{Author Recommendations.}

1. The position of independent KPK must be maintained by providing clear legal about the position of KPK through the establishment of legislation so that the KPK institutions cannot be intervened in terms of eradication of corruption in Indonesia

2. In order to these independent KPK institutions not to be abused by KPK officials, the recruitment of KPK members needs to be tightened and through a rigorous selection stage to obtain independent KPK officials, integrity and comrades against corruption eradication in Indonesia.

\section{Bibliography}

Alatas, S.H. (1999). Corruption and Destiny of Asia. Malaysia: Simon and Schuster.

Andi, H. (2011). Eradication of Corruption through National and International Criminal Law. Jakarta: Raja Grafindo Persada.

Bagir, M., (2001). The Development of Thought and Arrangement of Human Rights In Indonesia. Bandung: Publisher PT Alumni.

Creswell, J. (1994). Research Design: Qualitative, Quantitative, and Mixed Methods Approaches. London: Sage Publiation Inc.

Dirgha, I.G.A.N., Wirawan, T., \& Purnomo. (1985). Course Matrial of Constitutional Law, Published By : Department of Law of State, Faculty of Law, Universitas Negeri Jember. Mode.

Drehel, A and Christos, K. (2004). Corruption around the World: Evidence from a Structural

Hartanti, E. (2005). Corruption Crime. Jakarta: Sinar Grafika.

Ivon, R.V. Urgency Revocation of Right to Public Occupation for Corruption Actors, Journal of Law Faculty Brawijaya University, Malang.

James M. H. (2010). Sociology: A Down to Earth Approach. Boston: Allyn \& Bacon.

Klitgard, R. (1998). Eradicating Corruption. Jakarta: Yayasan Obor Indonesia.

Paiman Napitulu. (2007). Series of Governmental Sciences Towards Representative Government, Bandung: PT Alumni.

Patrick, B et.a. (2004). Understanding Local Level Conflict in Developing Countries: Theory, Evidence and Implication from Indonesia. Social Development Papers, Paper No.19, Washington DC.

Qamar, N. (2013). Human Rights In Democratic Law Country (Human Rights In 
Democratische Rechtsstaat). Jakarta: Sinar Grafika.

Rizky, A.I. (2013). Law, Human Rights and Democracy. Yogyakarta: Graha Ilmu.

Robert .K, et al. (2005). Corruption Eradication Guide In Local Government. Jakarta: Yayasan Obor.

Simanjuntak, B. (1981). Introduction to Criminology and Social Pantology. Jakarta: Tarsino.

Soemantri, S. (1993). State Institutions According to the 1945 Constitution. Ed. VII., Bandung: Citra Aditya Bakti.

Syamsuddin Radjab, DPR Parliamentary Questionnaire Against KPK A Critical Analysis, address: www.hukumonline.Com/berita/baca/lt5948e3, access dated 24 April 2018.

Yusti, P.R., (2005). Behind The Judge's Ruling: Legal Psychology Study In Criminal Case. Sidoarjo: Dieta Persada.

Wihoho, J., (2006). State institutions after the fourth amendment of the Constitution 1945. Surakarta: UNS Press

http://wikidpr.org/news/kompas-koras-politik-439-koruptor-handled-kpk-76-them-dpr-anddprd accessed on February 10, 2018.

http://www.indotesis.com/landasan-hukum-and-them-hack-space/\#sthash.oj7eUbfF.dpuf, accessed on 12 February 2018.

The 1945 State Constitution of the Indonesia Republic (UUD NRI 1945)

Law No. 27 of 2009 on MPR, DPR, DPD and DPRD.

Law No. 17 of 2014 on the MPR, DPR, DPD and DPRD.

Law No, 30 of 2002 on Corruption Eradication Commission.

Law No. 31 Year 1999 on the Eradication of Corruption.

Law No. 20 of 2001 on Amendment of Law No. 31 Year 1999 About the Eradication of Corruption.

Law No. 39 Year 1999 on Human Rights.

Азис Сетьягама, доктор философии, дочент, преподаватель юридического факультета, Университет Панча Марга, Индонезия, Восточная Ява, г. Проболинго

e-mail: Setyagama.azis@gmail.com

\section{Конституционное право на проведение расследований Комиссией по борьбе с коррупцией в Индонезии.}

В статье предпринята попьтка проанализировать права Комиссии по борьбе с коррупцией (КБК) по расследованию деятельности членов Законодательного собрания Индонезии. Это вызвано тем, что многие официальные лица заявляют о коррупционных деяниях, в которых подозреваются и члены Законодательного собрания, и обрашаются $в$ аппарат КБК с запросом о праве их участия в управлении бюджетом странь. Запрос касается и апелляии в связи с использованием членами Законодательного собрания при голосовании электронного удостоверения личности. В ходе анализа использовались положения Закона № 17/2014 о Народном консультативном конгрессе, Законодательном собрании, Совете региональных представителей и Совете народных представителей, а также Закона № 30/2002 о Комиссии по борьбе с коррупщией. Для изучения общественного мнения о праве на апелляцию в Законодательное собрание использовань результать соииологического опроса. Исследование показало, что право на расследование, данное Законодательным собранием, согласно Конституции является законным, поскольку оно выступает одним из трех прав Законодательного собрания. Тем не менее, право проведения опроса о законности использования электронного удостоверения личности, рассмотренное Законодательным собранием, фактически препятствует выполнению КБК своих обязанностей по предотвращению любого коррупиионного деяния в Индонезии. Кроме того, проведенный опрос также имеет свои плюсы и минусы, потому что общество еще не готово нему.

Ключевые слова: право на расследование; законодательное собрание; комиссия по 
борьбе с коррупцией; коррупционный акт; электронное удостоверение личности.

Надійшла до редколегії 25.05.2018 р.

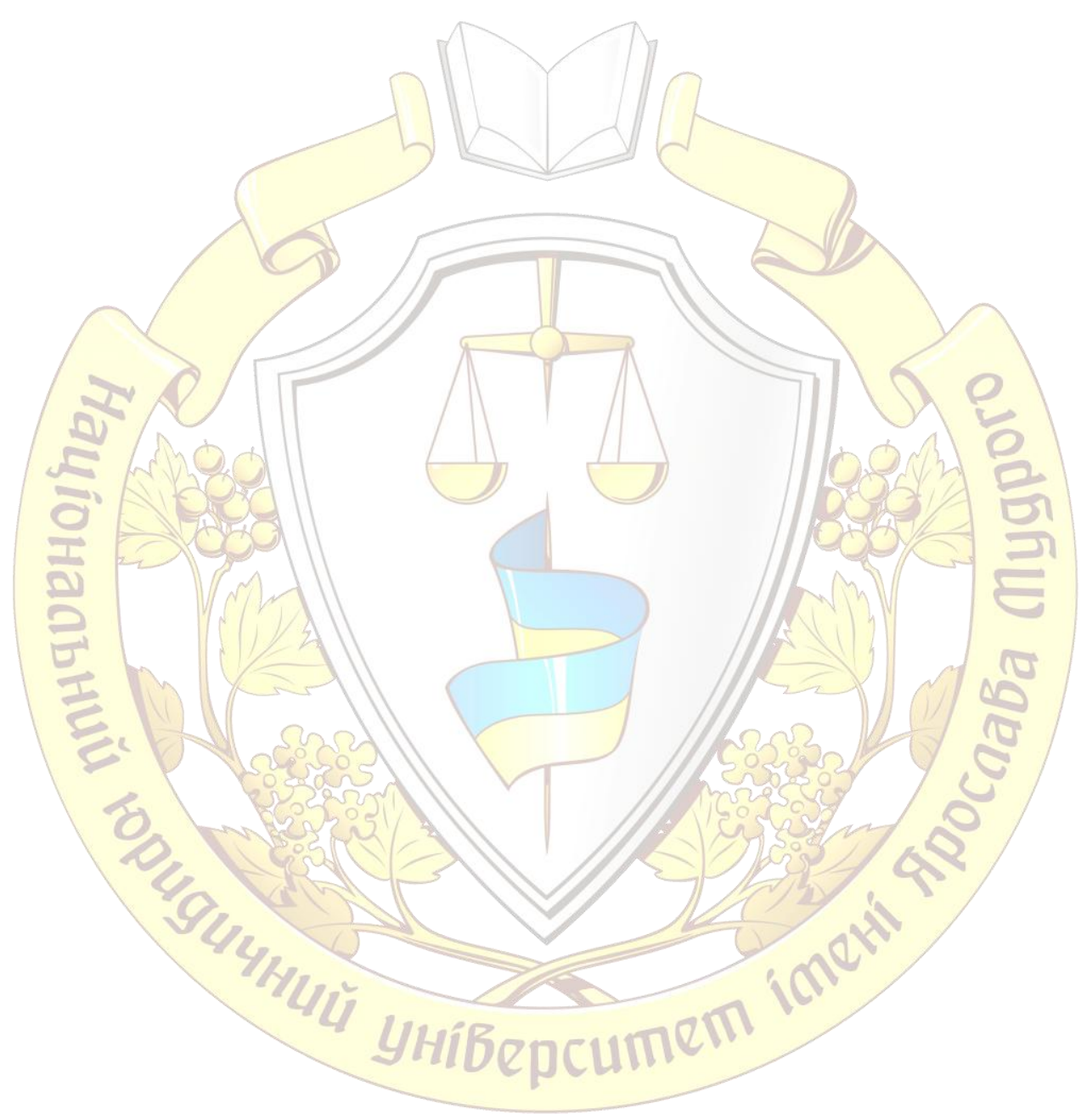

